\title{
Corporate Inversions And Fair Play
}

\author{
Scott L. Butterfield, Ph.D., Clayton State University, USA
}

Lou X. Orchard, Ph.D., Clayton State University, USA

\begin{abstract}
A Corporate inversion is a process that a company undergoes to change the domicile of the parent corporation in a multinational corporate conglomerate to a country other than the United States. J. S. Barry (2002) quotes U.S. Senator Max Baucus, Chairman of the Senate Finance Committee, as saying: "Prominent U.S. companies are literally re-incorporating in off-shore tax havens in order to avoid U.S. taxes. They are, in effect, renouncing their U.S. citizenship to cut their tax bill. This is very troubling, especially now, as we all try to pull together as a nation." Senator Charles Grassley (R-Iowa), the ranking Republican member of the Finance Committee, has called inversions "immoral." Stanley Works, a corporation based in Connecticut, planned to reincorporate in Bermuda. A Democratic Representative from that state, James Maloney, said, "Connecticut hasn't seen such a shameful day since Benedict Arnold sailed away." Stanley Works buckled under political pressure and did not go forward with the planned inversion. This paper addresses the current practice of corporate inversions, and reviews the current legal and political actions taken to address them.
\end{abstract}

Keywords: Corporate Inversion; Multinational Taxation; Earnings Stripping

\section{INTRODUCTION}

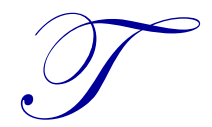

he practice of corporate inversions has led to cries in the U.S. Congress of "Unpatriotic corporate behavior!" J. S. Barry (2002) quoted Senator Max Baucus (D-Montana), Chairman of the Senate Finance Committee, as saying: "Prominent U.S. companies are literally re-incorporating in off-shore tax havens in order to avoid U.S. taxes. They are, in effect, renouncing their U.S. citizenship to cut their tax bill... This is very troubling, especially now, as we all try to pull together as a nation" (U.S. Senate Finance Committee 2002).

Senator Charles Grassley (R-Iowa), the ranking Republican member of the Finance Committee, has called inversions "immoral" (U.S. Senate Finance Committee 2002a). Stanley Works, a corporation based in Connecticut, planned to re-incorporate in Bermuda. A Democratic Representative from that state, James Maloney, said, "Connecticut hasn't seen such a shameful day since Benedict Arnold sailed away" (Barry 2002). Stanley Works buckled under political pressure and did not go forward with the planned inversion.

\section{WHAT IS A CORPORATE INVERSION?}

A corporate inversion is a process that a company undergoes to change the domicile of the U.S. parent corporation in a multinational corporate conglomerate to a country other than the United States. Corporations can accomplish this by either what are called stock inversions, asset inversions or a combination of the two. The most common method is to create a foreign subsidiary that, in turn, creates what is called a domestic merger subsidiary. The domestic merger subsidiary then merges into the U.S. corporation, creating a U.S. subsidiary of a foreign corporation. For stockholders of the U.S. corporation the shares of the old U.S. parent automatically become shares of the new foreign parent (Brumbaugh, 2003). Some companies of late that have re-incorporated are: IngersollRand, Tyco, Foster Wheeler, Nabors Industries, Coopers Industries, Seagate Technologies, Fruit of the Loom (a Berkshire Hathaway Company) and PricewaterhouseCoopers Consulting. One may ask why these international corporations are going to all the trouble to invert. The answer is profit - in particular, profit through tax savings. The United States has an international tax system that puts American firms at a competitive disadvantage relative to foreign corporations. The U.S. tax code taxes firms chartered in the 50 states and the District of Columbia on their 
worldwide income. On the other hand, corporations chartered in foreign countries are exempt from U.S. taxes on their foreign-source income. A few examples will make this difference very clear.

A company that is chartered in the United States has all income taxed at a current federal corporate tax rate of 35 percent. State corporate tax rates average an additional 5 percent. For the sake of simplicity, we will only concern ourselves with federal tax. Therefore, a company with $\$ 100$ million in taxable income earned within the U.S. will pay $\$ 35$ million in federal income taxes. Now, the Internal Revenue Code does provide a multinational corporation with foreign tax credits. These credits will offset the U.S. tax liability by the amount of foreign tax paid. Assume that the company in our example earns half of its income in the U.S. and the other half in Ireland. Ireland has a 12 percent corporate tax rate. The company in our example would pay $\$ 12$ million to the Irish government and \$23 million to the U.S. government. As you can see, the company is still paying 35 percent of its income in income taxes. U.S. companies have a marginal tax rate of at least 35 percent on all income.

Now suppose the company re-incorporates and is now chartered in Bermuda. Bermuda has no corporate income tax. Again, for the sake of argument, let us suppose that half the income was earned in the United States and the other half was earned in Ireland. This company would now pay 35 percent tax on the $\$ 50$ million earned in the U.S. to the U.S. government and 12 percent corporate tax on the $\$ 50$ million earned in Ireland to the Irish government. This amounts to a total tax liability of $\$ 23.5$ million, resulting in a tax savings of $\$ 11.5$ million. This is why corporations choose expatriation: the tax savings can be substantial.

The United States is one of the few countries that taxes worldwide income. Most other industrialized countries tax on the "territorial" principle, under which only income earned within their borders is subject to corporate income tax. Besides using this worldwide taxation method, the U.S. also has one of the highest corporate tax rates in the world. Two of the 30 countries - Japan, and Germany - in the Organization for Economic Cooperation and Development (OECD) have higher corporate tax rates than the United States. When combining the average state income tax rate with the federal rate, the United States effectively has a rate that is 9 percent higher than the average OECD top corporate rate of 31.4 percent (Congressional Budget Office, 2005). The rates of some countries are significantly lower than that of the U.S. As pointed out earlier, Ireland's income tax rate is 12 percent; while Switzerland's corporate tax rate is 8 percent (Barry, 2002). Other countries have instituted major tax reforms in the last few years in an attempt to make their economies attractive for investment. The average corporate tax rate in the OECD has dropped 6 percent since 1996. The United States corporate rate, on the other hand, has not changed in many years. The United States' high tax rate puts American international firms at a disadvantage when competing in worldwide markets.

\section{THE COST OF CORPORATE INVERSIONS}

The shareholders of a company carry the majority of the cost of a corporate inversion in the short term. Capital gains taxes may be required on any increase in fair market value of the stock from the time of purchase to when the old shares are traded for the new foreign parent company shares. This may be why corporate inversions have been popular in the past year or so. The depressed stock market will lead to lower shareholder costs in the form of lower capital gains taxes. Of course, the only reason that shareholders agree to a corporate inversion is for the possible savings and stock value increase in the long term. For example, when Stanley Works was considering reincorporating, the executives estimated that the shareholders would pay up to $\$ 150$ million in capital gains taxes at the time of the inversion. However, the firm estimated that the tax savings would be approximately $\$ 30$ million per year. The present value of these payments assuming an interest rate of 2.5 percent over the next ten years would be almost $\$ 263$ million. Finally, the company believed that the inversion would increase the company's stock value by 11.5 percent. As of May 22, 2002, the date of the estimates, Stanley Works had a total market capitalization of $\$ 4.1$ billion. Unfortunately for Stanley Works' shareholders, the company caved in to the negative publicity drummed up by politicians and did not move forward with the inversion (Ebeling, 2002).

Companies can avoid paying taxes on U.S. source funds though a method called "earnings stripping." Earnings stripping happens when a corporation transfers money to the foreign parent by way of tax-deductible payments, such as interest payments. Assume that the parent foreign country "lends" the U.S. subsidiary $\$ 100$ million. As long as the interest rate is competitive, the loan would satisfy the "arms length" rule of transactions 
between related parties. In this instance, if the interest rate is 5 percent, then the U.S. subsidiary can pay the parent corporation $\$ 5$ million in tax-deductible interest. However, as the U.S. Treasury Department has noted, earnings stripping is not confined to inversions, but also occurs within foreign-controlled groups in general (Brumbaugh, 2003).

\section{ARE CORPORATE INVERSIONS TAX EVASION METHODS?}

Politicians complain that re-incorporated companies are tax dodgers and unpatriotic tax evaders. The Democratic Staff of the Ways and Means Committee (2003) made these comments and quoted others concerning corporate inversions:

- $\quad$ Congress must not allow corporate traitors to leave individual Americans stuck with the tax bill while they put profits over patriotism. The New York Times says, "Even in the best of times, it is outrageous for companies to engage in offshore shenanigans to avoid paying their fair share of taxes. Doing so after the Enron scandal, in dire fiscal times and when the nation is at war is unconscionable."

Should companies pay more taxes than they are legally required to? Judge Learned Hand (1934) stated:

- $\quad$ Anyone may so arrange his affairs that his taxes shall be as low as possible; he is not bound to choose that pattern which will best pay the Treasury. There is not even a patriotic duty to increase one's taxes. This idea of paying the minimum amount of taxes under the law should apply to business as well as individuals.

As the Honorable Judge states, it is not patriotic to pay more taxes than necessary. If fact, it is not fiscally sound to pay more tax than required.

A corporation's duty to its stakeholders is to earn a profit. Specifically, it is to earn the most profit possible under legal means. It is true that the government is a stakeholder of a corporation and it could be argued that payment of excessive taxes will benefit that one stakeholder. However, the increase in profit from paying lower taxes will benefit all stakeholders. The government will benefit in the long term from an increase in profit in several ways. The first is by an increase in capital gains taxes, brought about by an increase in stock value, or an increase in taxes on dividends if those additional profits are paid to stockholders. Secondly, the firm's products or services will have more competitive pricing which will increase the number of units sold. Of course, the government will tax increases in revenue and productivity in various ways: sales tax, property tax, employment taxes, etc. ${ }^{1}$ Many economists would argue that an increase in productivity is the best way for a government to receive increases in taxes. Reducing corporate state income tax is the reason that so many companies incorporate in the state of Delaware. Approximately 308,000 companies have chartered in Delaware. Among these are 60 percent of Fortune 500 companies and half of the companies listed on the New York Stock Exchange (Ebeling, 2002). When evaluating a job offer in a different location, economic theory says that individuals should take into account whether the state or locality levies individual income tax and at what rate. This is simply a matter of individuals maximizing their income.

\section{WHAT IS A POLITICIAN TO DO?}

The idea of tax dollars floating away with these offshore moves has politicians scurrying to write new laws. One of the bills, the Corporate Patriot Enforcement Act, introduced by U.S. Representative Richard Neal (DMassachusetts), was written to continue levying U.S. corporate tax on the foreign source income in corporate expatriation transactions. A corporate expatriation transaction would be any transaction in which:

- $\quad$ A U.S. corporation becomes a subsidiary of a "nominally foreign corporation" or otherwise transfers substantially all of its properties to such a corporation; and

\footnotetext{
${ }^{1}$ Total revenues will increase in the long run if demand is inelastic or if there are barriers to entry; total revenues might increase if demand is elastic.
} 
- $\quad$ The former shareholders of the U.S. corporation hold more than 80 percent (by vote or value) of the stock of the "nominally foreign corporation" immediately after the transaction. In addition, this 80 percent test would be lowered to 50 percent in the event that (a) the "nominally foreign corporation" does not have substantial business activities in the corporation's country of incorporation (compared to the total business activities of the corporations and all companies connected to it by a chain of 50 percent or greater (ownership), and (b) the stock of the corporation is traded principally in the U.S. public market (Joint Committee on Taxation, 2002).

Representative Neal was not alone or unique with his bill. There were five other bills with very similar language introduced into the House and Senate. The Neal bill would also not allow these companies to secure government contracts. According to Representative Rangel, a supporter of this bill, "If these companies flee their responsibilities to America in its time of need, then they and their executives do not deserve the benefits of America's protection, economic environment, and government contracts. Representative Rangel does not mention securing government contracts that provide the best service at the best cost for the American public.

\section{WHAT IS THE REAL PROBLEM?}

Corporate inversions are a symptom of a problem with the United States corporate tax code. The current tax code places American chartered companies in an uncompetitive situation in the world economy. The taxation of worldwide income is thought to be a reason why Daimler-Chrysler established its headquarters in Germany, not in Detroit (de Rugy, 2002).

There is some hope that our representatives on Capitol Hill are beginning to see the light. The House of Representatives stated:

It is the sense of Congress that passage of legislation to fix the underlying problems with our tax laws is essential and should occur as soon as possible, so United States corporations will not face the current pressures to engage in inversion transactions (Barry, 2002).

The U.S. Treasury Department issued a report entitled, "Corporate Inversion Transactions: Tax Policy Implications" (2002). Within the report, the Treasury states that the policy response to the recent corporate inversion activity should be broad enough to address the underlying differences in the tax treatment of U.S. based companies and foreign-based-companies, without regard to how foreign-based status is achieved. Measures designed simply to halt inversion activity may address these transactions in the short run, but there is a serious risk that measures targeted too narrowly would have the unintended effect of encouraging a shift to other forms of transactions to the detriment of the U.S. economy in the long run (Ebeling, 2002).

American policy, whether tax or legal, should promote American business within and outside our borders. The Austrian economist Joseph A. Schumpeter suggested in an essay entitled "The Crisis of the Tax State" (1919) that a nation's fiscal system can serve as a useful basis for a history of that country's rise and fall, since the tax system and its structure reflect the political and ideological ideas of that society through time (Ebeling, 2002). Corporate inversions are giving the American public a wakeup call to a serious problem that can and will keep our country from being competitive in global markets.

\section{AUTHOR INFORMATION}

Scott Butterfield, Ph.D., has spent 16 years in academia, teaching in undergraduate and graduate programs of several universities. His research interests lie in the areas of Taxpayer Behavior, Taxes and Public Policy, and Managerial/Cost Accounting. Prior to his academic career, Dr. Butterfield worked for Coopers \& Lybrand where he performed consulting and compliance work for a variety of clients in varied industries, including: Banking, Manufacturing, Restaurant/Food Services, Biotech, Electric Co-Generation, and Non-Profit, as well as for high-networth individuals. Associate Professor, Clayton State University, 2000 Clayton State Boulevard, Morrow, Georgia, 30260-0285, USA. E-mail: ScottButterfield@mail.clayton.edu (Corresponding author) 
Lou X. Orchard, Ph.D., is an Assistant Professor at Clayton State University, Morrow, Georgia. He received his B.A. degree in Business Administration (Accounting) and his MBA from the University of Washington, and his Ph.D. in Business Administration (Accounting) from the University of Arizona. In addition to these schools, Dr. Orchard has also taught accounting at the University of Houston and Wichita State University. He has worked for what is now a Big Four CPA firm, as well as a commercial real estate company. Assistant Professor, Clayton State University, 2000 Clayton State Boulevard, Morrow, Georgia, 30260-0285, USA. E-mail: LouOrchard@clayton.edu

\section{REFERENCES}

1. Americans for Tax Reform (2003). Setting the Story Straight: The Truth About Corporate Inversion.

2. Barry, J. S. (2002). Corporate Inversions: An Introduction to the Issue and FAQ. Tax Bites. Tax Foundation. Retrieved on Dec. 13, 2012 from http://taxfoundation.org/article/corporate-inversionsintroduction-issue-and-faq

3. Brumbaugh, D. L. (2003). Firms That Incorporate Abroad for Tax Purposes: Corporate "Inversions" and "Expatriation". CRS Report for Congress. (RL31444).

4. Congressional Budget Office. (2005). Corporate Income Tax Rates: International Comparisons. Washington, DC: U.S. Government Printing Office. Retrieved from: http://www.cbo.gov/sites/default/files/cbofiles/ftpdocs/69xx/doc6902/11-28-corporatetax.pdf

5. Corporate Expatriation: Protecting American Jobs (2003, November). http:www.freedoman.html (2003 November 19).

6. Democratic Staff of the Ways and Means Committee (2003). Information Sheet: Democrats fight to close Bermuda Triangle tax loophole. (Updated 2003 May 12).

7. De Rugy, V. (2002 May 14). [Letter to the Editor]. The New York Times.

8. $\quad$ Ebeling, R. M. (2002). Corporate Inversions and the Tax State. Freedom Daily.

9. Fairfax, VA: The Future of Freedom Foundation. (2003 November 19).

10. Hufbauer, G. C. (2002, June). Corporate Inversions. Testimony before the Committee on Ways and Means, United States House of Representatives, Washington DC. Joint Committee on Taxation. (2002).

11. Sommers, R. L. (2003). Background and Description of Present-Law Rules and Proposals Relating to corporate Inversion Transactions.

12. U.S. Senate Finance Committee (2002), Baucus Statement upon Introduction of Inversion Legislation. April 11. Retrieved on Dec. 13, 2012 from http://www.finance.senate.gov/newsroom/chairman/release/?id=88d6beab-fe91-4e9d-a4cd-2f60147cb6df

13. U.S. Senate Finance Committee (2002a), Grassley Announces Bill to Rein in Corporate Expatriation. April 11. Retrieved on Dec. 13, 2012 from http://www.finance.senate.gov/newsroom/ranking/release/?id=c084249c-2113-476b-a2bd-ad2efbdce01d 


\section{NOTES}

